JAHR, Vol. 1, No.1, Juni 2020

Journal of Aafiyah Health Research (JAHR)

$P$-ISSN : 2722-4929 \& E-ISSN : 2722-4945

Published by Postgraduate Program in Public health, Muslim University of Indonesia

\title{
Pengaruh Hypnobirthing Terhadap Penanggulangan Nyeri Pada Masa Persalinan Di UPT Puskesmas Sukamaju Kab. Luwu Utara
} Tahun 2020

\author{
Muji Rahayu ${ }^{1}$, Fatmah Afrianty Gobel $^{2}$, Een Kurnaesih ${ }^{2}$ \\ 1,2, 3 Pascasarjana Universitas Muslim Indonesia \\ Email: mujirahayuas@yahoo.co.id
}

\begin{abstract}
Background: Pain that occurs at the time of normal childbirth Primigravida mother encourages using pain-overcome drugs such as analytic and sedative. One of The nonpharmacological methods To reduce the pain intensity of Childbirth Is The method of hypnobirthing. This research is done with the aim to analyze the effect of hypnobirthing on pain management in the maternity period of motherPrimigravida in Upt Public Health Center of Sukamaju. Method: this type of research is an research quantitative study with a quasi experimental method, namely the experimental design with the observation method (pain intensity measurement) before and after treatment of Hypnobirthing and control group. Sampling was done by accidental sampling method Number of samples of the intervention group (Hypnobirthing) as much as 12 respondents and a control group of 9 respondents. Data analysis methods using Univariate and bivariate analytic with Test T-Test. Result: Statistical test result obtained $\rho$ value amounting to 0.000 at an error rate of $(\alpha) 5 \%$ or 0.05 (trust $95 \%$ ) so that the value $\rho<\alpha$. The Data suggests that there is a significant influence on Hypnobirthing treatment against pain overcome during childbirthThe results of the study could average the intesity of pain in maternity mothers after given Hypnobirthingdecreased while the control class experienced an increase. Hypnobirthing method can reduce pain intensity in maternity while in the control group it increases pain. Conclusion: an influence of hypnobirthing against pain overcome on childbirth in UPT Public Health center of district Sukamaju North Luwu.
\end{abstract}

Keywords: Pain, Normal Childbirth, Primigravida, hypnobirthing. 


\begin{abstract}
ABSTRAK
Latar belakang: Nyeri yang timbul pada saat persalinan normal ibu primigravida mendorong menggunakan obat penawar nyeri seperti analgetik dan sedative.Salah satu metode nonfarmakologi untuk mengurangi intensitas nyeri pada masa persalinan adalah metode Hypnobirthing.Penelitian ini dilakukan dengan tujuan untuk menganalisis pengaruh Hypnobirthing terhadap penanggulangan Nyeri pada masa persalinan ibu Primigravida di UPT Puskesmas Sukamaju. Metode: Jenis penelitian ini adalah penelitian kuantitatif eksprimental dengan metodeQuasi Eksperimen, yaitu rancangan eksperimen dengan metode observasi (Pengukuran intensitas nyeri) sebelum dan setelah perlakukan hypnobirthing dan kelompok kontrol. Pengambilan sampel dilakukan dengan metode accidental samplingjumlah sampel kelompok intervensi (hypnobirthing) sebanyak 12 responden dan kelompok kontrolsebanyak 9 responden. Metode analisis data menggunakan analsis Univariat dan Bivariat dengan Uji T-Test. Hasil: hasil uji statistik diperoleh $\rho$ value sebesar 0,000 pada tingkat kesalahan sebesar $(\alpha) 5 \%$ atau 0,05 (kepercayaan 95\%) sehingga nilai $\rho<\alpha$. Data tersebut menunjukkan bahwa ada pengaruh yang signifikan perlakuan hypnobirthing terhadap penanggulangan rasa nyeri pada masa persalinan. Metode hypnobirthing dapat menurunkan intesitas nyeri pada ibu bersalin sedangkan pada kelompok kontrol mengalami peningkatannyeri. Kesimpulan: ada pengaruh Hypnobirthing terhadap penanggulangan nyeri pada persalinan di UPT Puskesmas Sukamaju Kab.Luwu Utara.
\end{abstract}

Kata Kunci: Nyeri, Persalinan Normal, Primigravida, Hypnobirthing.

\section{LATAR BELAKANG}

Proses persalinan merupakan serangkaian kejadian yang diawali dengan pengeluaran bayi cukup bulan atau hampir cukup bulan disertai dengan pengeluaran placenta dan selaput janin dari jalan lahir. Persalinan dikatakan normal bila bayi lahir dengan presentasi belakang kepala tanpa memakai alat-alat atau pertolongan istimewa serta tidak melukai ibu dan bayi, umumnya berlangsung dalam waktu kurang dari 24 jam. Persalinan normal (eutosia), adalah proses kelahiran janin pada kehamilancukupbulan (aterm) pada letak memanjang dan presentasi belakang kepala disusul dengan pengeluaran placenta dan seluruh proses persalinan berakhir dalam waktu kurang dari 24 jam, tanpa tindakan dan tanpa komplikasi (1).

Persalinan secara normal terjadi

pada ibu hamil dengan usia kehamilan aterm (37 minggu-42 minggu). Pada proses persalinanibu harus mampu mengeluarkan janin secara spontan dari rahim melalui jalan lahir tanpa membahayakan ibu dan janinnya. Pada masa persalinan dan kelahiran ini merupakan waktu yang mengandung resiko baik terhadap ibu maupun janin

Pada proses persalinan tentu banyak hal yang terjadi pada tubuh ibu maupun terhadap tubuh janin, salah satu yang terjadi pada masa persalinan yaitu adanya rasa nyeri yang di rasakan oleh ibu, hal ini merupakan kejadian yang normal atau alamiah, tetapi banyak ibu-ibu yang tidak memahami bahwa rasa sakit itu baik dalam proses persalinan.Hal ini disebabkan adanya perubahan dalam tubuh tertutama pada uterus, karena pengaruh dari kerja hormonal yang terjadi masa persalinan.

Kondisi nyeri yang timbul pada proses persalinan memungkinkan para ibu cenderung memilih cara yang paling gampang dan cepat untuk menghilangkan rasa nyeri, maka berbagai upaya dilakukan untuk menurunkan nyeri pada persalinan baik secara farmakologi maupun non farmakologi. Nyeri persalinan yang tidak 
tertahankan mendorong ibu bersalin menggunakan obat penawar nyeri seperti analgetik dan sedativa, sedangkan obatobat tersebut memberikan efek samping yang merugikan yang meliputi fetal hipoksia, resiko depresi pernapasan neonatus, penurunan Heart Rate/Central Nervus System (CNS) dan peningkatan suhu tubuh ibu yang dapat menyebabkan perubahan pada janin (2).

Rasa nyeri persalinan adalah nyeri kontraksi uterus yang dapat mengakibatkan peningkatan aktivtas sistem syaraf simpatis. Nyeri yang hebat pada persalinan dapat menyebabkan perubahanperubahan fisiologi tubuh seperti: tekanan darah menjadi naik, denyut jantung meningkat, laju pernafasan meningkat, dan apabila tidak segera diatasi, maka akan mengakibatkan rasa khawatir, tegang, takut, dan stress. Peningkatan konsumsi glukosa tubuh pada ibu bersalin yang mengalami stres menyababkan kelelahan dan sekresi katekolamin yang menghambat kontraksi uterus, hal tersebut menyebabkan persalinan lama yang akhirnya menyebabkan cemas pada ibu, peningkatan nyeri dan stres berkepanjangan (Bobak dkk, 2004).

Selain itu, nyeri yang terjadi dapat mempengaruhi kondisi ibu berupa kelelahan, rasa takut, khawatir menimbulkan stres. Stres dapat menyebabkan melemahnya kontraksi rahim dan berakibat pada persalinan yang lama (4). Menurut Galih dkk Saat ini hampir 20-50\% persalinan di Rumah Sakit Swasta dilakukan dengan Sectio Caesaria. Hal ini dikarenakan ibu-ibu yang hendak bersalin lebih memilih operasi karena tidak ingin merasakan nyeri. Di Brazil, operasi Sectio Caesaria mencapai $50 \%$ yang merupakan persentase tertinggi diseluruh dunia (5).

Berbagai metode non farmakologi yang dapat dilakukan oleh ibu untuk menanggulangi rasa nyeri pada masa persalinan, diantaranya dengan mengatur pola pernapasan dalam(2), vikalisasi, mandi siram, senam yoga, akupuntur dan akupresure (6).Salah satu upaya untuk mengurangi intensitas nyeri pada ibu primigravida yang akan melakukan persalinan adalah menginformasikan persalinan aman dan nyaman dengan melakukan metode hypnobirthing.Metode ini dikembangkan oleh seorang bidan yang bernama Lanny Kuswandi melalui Pater Jacson di Australia yang membuat sadar bahwa wanita merupakan manusia yang sangat istimewa dan pada tahun 2003 di Indonesia mulai disebarluaskan metode ini (7).

Beberapa negara seperti Amerika Serikat telah dikembangkan metode hypnobirthing.Metode ini merupakan metode alamiah yang digunakan untuk menghilangkan rasa takut, panik, tegang dan tekanan-tekanan lain yang menghantui ibu selama persalinan. Hypnobirthing di sinyalir banyak memberikan manfaat karena melatih ibu hamil untuk selalu rileks, bersikap tenang dan menstabilkan emosi. Hypnobirthing bertujuan agar ibu dapat melahirkan dengan nyaman dan menghilangkan rasa sakit melahirkan tanpa bantuan obat bius apapun(8).Metode inididasarkan pada keyakinan bahwa setiap perempuan memiliki potensial untuk menjalani proses melahirkan secara alami,tenang, dan nyaman (tanpa rasa sakit)(9).

Hypnobirthing ini tidak memiliki potensi efek samping terhadap bayi, mampu menghadirkan rasa nyaman, rileks, dan aman menjelang kelahiran, membuat ibu mampu mengontrol sensasi rasa nyeri pada saat kontraksi uterus, persiapan hypnobirthing bermanfaat bagi semua keluarga, termasuk mereka yang karena memang mengalami suatu keadaan khusus, berada dalam kategori resiko tinggi jika persalinan mereka berlangsung tidak seperti yang diharapkan (10).

Hasil penelitian yang dilakukan oleh Eka Sriwahyuni dkk (2019) di Rumah Sehat Kasih Bunda menunjukkan sebagian besar sampel penelitian menyatakan bahwa dengan dilakukannya teknik relaksasi hypnobirthing merasakan adanya 
penurunan nyeri kala I. Hasil analisis statistik terhadap penurunan nyeri kala I dengan menggunakan program komputerisasi menunjukkan nilai $\rho$ value $=$ 0.000 . Sebab nilai $\rho$ value $<0.05(95 \%$ kepercayaan), maka Ho ditolak artinya ada pengaruh dilakukannya teknik relaksasi hypnobirthing terhadap penurunan rasa nyeri kala I persalinan normal pada primipara (11).

Berdasarkan hasil studi pendahuluan yang yang dilakukan di Puskesmas Sukamaju melalui wawancara dan observasi kepada 6 ibu primigravida yang berkunjung ke Puskesmas Sukamaju Kab.Luwu Utara, diperoleh ibu yang mengalami ketakutan akibat nyeri yang dirasakan saat akan menghadapi persalinan sehingga menyebabkan ketidaknyamanan pada kehamilan pertamanya. semua ibu hamil tersebut belum pernah melakukan metode hypnobirthing selama kehamilannya.

Berdasarkan latar belakang tersebut peneliti tertarik untuk meneliti tentang Pengaruh Hypnobirthing terhadap penanggulangan Nyeri pada masa Persalinan.

\section{METODE}

Penelitian ini dilaksanakan di UPT Puskesmas Sukamaju Kab. Luwu Utara pada bulan Maret - Mei Tahun 2020. Pendekatan yang digunakan adalah eksperimen yang bersifat kuantitatif, yaitu Quasy Eksperiment. Desain penelitian yang digunakan adalah Nonequivalent Control Group Design,untuk mengetahui adanya pengaruh hypnobirthing terhadap penanggulangan rasa nyeri pada saat persalinan.

Populasi dalam penelitian ini adalah ibu primigravida yang bersalin normal di UPT Puskesmas Sukamaju Tahun 2020 dengan jumlah sampel 21 responden yang terdiri dari 12 responden kelompok hypnobirthingdan9 responden kelompok control.Instrumen yang digunakan berupa kuesioner yang berisi data pribadi dan lembar observasi kondisi responden. Pengukuran intensitas nyeri dengan menggunakan Visual Analog Scale (VAS) dan Verbal Descriptor Scale (VDS).

Analisis univariat dilakukan dari tiap variabel dari hasil penelitian berupa distribusi frekuensi dan presentase tiap variabel. Analisis bivariat merupakan analisis untuk mengetahui hubungan antara variabel independen dan variabel dependen dengan meggunakan data ordinal, terlebih dahulu dilakukan uji normalitas data menggunakan uji one sample kolmogorovsmirnov, apabila data terdistribusi normal dilanjutkan dengan independent sample $t$ test dengan taraf signifikan $(\alpha) 0,05$ atau tingkat kepercayaan $95 \%$.

Metode estimasi untuk pengukuran data yang terkumpul diolah dengan mengubah data menjadi informasi, melalui tahapan sebagai berikut: penyunting data (Editing), pengkodean (Coding), entri data, tabulasi (Tabulating). Uji statistik yang digunakan adalah uji univariat dan bivariat dengan menggunakan Program Statistical Product and Service Solution (SPSS). 


\section{HASIL PENELITIAN}

\section{Analisis Univariat}

Tabel 1. Distribusi Frekuensi Hubungan antara Umur dengan Intesitas Nyeri pada Ibu Primigravida dengan Persalinan Normal Di UPT Puskesmas Sukamaju Kab. Luwu Utara Tahun 2020

\begin{tabular}{|c|c|c|c|c|c|c|c|c|}
\hline \multirow{3}{*}{ Intensitas Nyeri } & \multicolumn{8}{|c|}{ Frekuensi Kelas Bredasarkan Umur (Tahun) } \\
\hline & \multicolumn{3}{|c|}{$\begin{array}{c}\text { Intervensi } \\
\text { (Hypnobirthing) }\end{array}$} & \multicolumn{3}{|c|}{ Kontrol (KIE) } & \multirow[b]{2}{*}{$>35$} & \multirow[b]{2}{*}{$\mathbf{F}(\%)$} \\
\hline & $<25$ & $25-35$ & $>35$ & $\mathbf{F}(\%)$ & $<25$ & $25-35$ & & \\
\hline \multicolumn{9}{|l|}{ Pre Test } \\
\hline Nyeri Ringan & - & - & - & 0,00 & 1 & 3 & - & 44,44 \\
\hline Nyeri Sedang & 2 & 3 & 1 & 50,00 & 1 & 1 & 1 & 33,33 \\
\hline $\begin{array}{l}\text { Nyeri Berat } \\
\text { Terkontrol }\end{array}$ & 2 & 1 & 1 & 25,00 & - & 1 & - & 11,11 \\
\hline $\begin{array}{l}\text { Nyeri Berat tidak } \\
\text { Terkontrol }\end{array}$ & 2 & - & 1 & 25,00 & - & 1 & - & 11,11 \\
\hline \multicolumn{9}{|l|}{ Post Test } \\
\hline Nyeri Ringan & 1 & 1 & - & 16,67 & - & - & - & 0,00 \\
\hline Nyeri Sedang & 4 & 3 & 1 & 66,67 & 2 & 4 & - & 66,67 \\
\hline $\begin{array}{l}\text { Nyeri Berat } \\
\text { Terkontrol }\end{array}$ & 1 & - & 1 & 16,67 & - & 1 & 1 & 22,22 \\
\hline $\begin{array}{l}\text { Nyeri Berat tidak } \\
\text { Terkontrol }\end{array}$ & - & - & - & - & - & 1 & - & 11,11 \\
\hline
\end{tabular}

Tabel 1 menunjukkan bahwa saat pre test, kelas intervensi (hypnobirthing) terdapat 6 $(50 \%)$ responden dengan nyeri sedang, sedangkan kelas kontrol terdapat 4 $(44,44 \%)$ responden dengan nyeri ringan. Pada saat post test didapatkan pada kelas intervensi (hypnobirthing) terdapat 8 $(66,67 \%)$ responden dengan nyeri sedang kelompok kontrol (KIE) terdapat 6 $(66,67 \%)$ responden sedang.
Untuk mengetahui apakah data variabel independen dan variabel dependen terdistribusi secara normal atau tidak, maka dilakukan uji normalitas. Data yang baik adalah memiliki distribusi data normal atau mendekati normal. Untuk uji normalitas, dapat dianalisis dengan menggunakan metode one-Sample Kolmogorov-Smirnov testseperti ditunjukkan pada tabel 2 berikut ini. 
Tabel 2. Hasil Uji Normalitas Kelompok Intervensi (Hypnobirthing) dan Kelompok Kontrol (KIE)

\begin{tabular}{|c|c|c|c|c|c|c|c|}
\hline \multirow{3}{*}{ Variabel } & \multicolumn{6}{|c|}{ Kelompok } & \multirow{3}{*}{$\begin{array}{c}\text { Level of } \\
\text { Significant }\end{array}$} \\
\hline & \multicolumn{3}{|c|}{ Intervensi (Hypnobirthing) } & \multicolumn{3}{|c|}{ Kontrol (KIE) } & \\
\hline & $\begin{array}{l}\text { Pre } \\
\text { Test } \\
\end{array}$ & $\begin{array}{l}\text { Post } \\
\text { Test } \\
\end{array}$ & Ket & $\begin{array}{l}\text { Pre } \\
\text { Test }\end{array}$ & $\begin{array}{l}\text { Post } \\
\text { Test }\end{array}$ & Ket & \\
\hline Sig. (2-tailed) & 0,376 & 0,518 & Normal & 0,356 & 0,748 & Normal & 0,05 \\
\hline
\end{tabular}

Berdasarkan tabel 2 di atas, hasil uji normalitas dengan metode one sample di atas terlihat bahwa nilai sig. (2tailed)>level of significant $=0,05$ baik kelompok intervensi maupun kelompok kontrol, sebelum dan setelah pre test dan post test. Dengan demikian, maka variabel independen dan dependen mempunyai distrubusi data normal.

\section{Analisis Bivariat}

Tabel 3. Hasil Uji T- Tes Perbandingan Kelompok Intervensi (Hypnobirthing) dan Kelompok Kontrol (KIE) terhadap penanggulangan nyeri persalinan di UPT Puskesmas Sukamaju Kab. Luwu Utara Tahun 2020

\begin{tabular}{|c|c|c|c|c|c|}
\hline \multirow{2}{*}{ Kelompok } & \multirow{2}{*}{$\mathrm{N}$} & \multicolumn{2}{|c|}{ Intensitas Nyeri (Mean \pm SD) } & \multirow{2}{*}{$\mathrm{t}$} & \multirow{2}{*}{$\rho$} \\
\hline & & Mean & Perbedaan & & \\
\hline $\begin{array}{l}\text { Intervensi } \\
\text { (Hypnobirthing) }\end{array}$ & \multirow{3}{*}{12} & & & & \\
\hline Pre Test & & $7,750 \pm 1,712$ & \multirow{2}{*}{$2,250 \pm 0,866$} & \multirow{2}{*}{9,000} & \multirow{2}{*}{0,000} \\
\hline Post Test & & $5,500 \pm 2,023$ & & & \\
\hline Kontrol (KIE) & \multirow{3}{*}{9} & & & & \\
\hline Pre Test & & $5,000 \pm 2,739$ & \multirow{2}{*}{$-1,333 \pm 1,225$} & \multirow{2}{*}{$-3,266$} & \multirow{2}{*}{0,011} \\
\hline Post Test & & $6,330 \pm 2,236$ & & & \\
\hline
\end{tabular}

Berdasarkan tabel 3 dari 12 responden kelompok intervensi diketahui penurunan intensitas nyeri persalinan 2,250 $\pm 0,866$ dan kelompok kontrol (KIE) dengan 9 responden mengalami peningkatan 1,333 $\pm 1,225$.Pada kelas intervensi (hypnobirthing) pengujian bivariat dilakukan uji $\mathrm{t}$ pada tingkat kesalahan sebesar $(\alpha) \quad 5 \%$ atau 0,05 (kepercayaan 95\%) diperoleh $\mathrm{t}_{\text {tabel }}=1,782$ dan diperoleh nilai $t_{\text {hitung }}=9,000$; sehingga nilai $t_{\text {hitung }}>t_{\text {tabel }}$ artinya $\mathrm{H}_{0}$ ditolak dan $\mathrm{H}_{\mathrm{a}}$ diterima. Berdasarkan data hasil pengujian yang diperoleh dapat diketahui bahwa hypnobirthing memiliki pengaruh dalam mengurangi rasa nyeri selama persalinan.

\section{DISKUSI}

1. Nyeri Persalinan Sebelum dilakukan Hypnobirthing

Rasa nyeri yang dialami responden pada saat persalinan dikarenakan adanya perubahan fisiologi dari jalan lahir dan rahim. Hasil ini didukung oleh teori Bandiyah (2009) bahwa nyeri persalinan disebabkan oleh proses dilatasi servik, 
iskemia korpus uteri dan peregangan segmen bawah rahim dan kompresi saraf di servik.

Menurut Hidayat (2009) bahwa nyeri tergantung dari kerja serta saraf besar dan kecil yang berada dalam akar ganglion dorsalis. Rangsangan pada saraf besar akan meningkatkan mekanisme aktivitas substansia gelatinosa yang mengakibatkan tertutupnya pintu mekanisme sehingga aktivitas sel $\mathrm{T}$ terhambat dan menyebabkan hantaran rangsangan ikut terhambat. Rangsangan pada serat kecil akan menghambat aktivitas substansia gelatinosa dan membuka pintu mekanisme, sehingga merangsang aktivitas sel $\mathrm{T}$ yang selanjutnya akan menghantarkan rangsangan nyeri.

Pada penelitian ini intesitas nyeri pada responden bervariasi baik pada kelompok yang dilakukan hypnobirthingmaupun yang tidak dilakukan hypnobirthing. Berdasarkan tabel 1 pada penelitian ini sebelum dilakukan hypnobirthing, responden yang mengalami nyeri berat dan nyeri berat tidak terkontrol adalah responden yang berusia < 25 tahun yaitu sebanyak 4 $(33,33 \%)$ dan responden yang mengalami nyeri sedang adalah responden yang berusia 25 - 35 yaitu sebanyak $3(25 \%)$. Hal yang sama dihasilkan dalam penelitian Magfiroh (2012) dalam Adam dan Umboh (2015) bahwa umur ibu yang < 25 tahun lebih merasakan nyeri hebat dibandingkan dengan umur yang berusia 25 - 35 tahun.

Hal ini disebabkan karena usia muda seseorang belum memiliki pengalaman yang cukup terkait persalinan dan nyeri sehingga mempersepsikan nyeri lebih berat dibanding yang berusia lebih tua. Selain itu, umur muda memiliki sensori nyeri lebih intens dibanding dengan ibu yang memiliki umur yang lebih tua. Umur muda cenderung dikaitkan dengan kondisi psikologis yang masih labil yang memicu terjadinya ketakutan dan kecemasan sehingga nyeri yang dirasakan semakin lebih kuat. Umur juga dipakai sebagai salah satu faktor dalam menentukan toleransi terhadap nyeri (12).

Menurut Sulistyawati (2012) dalam Eka Sriwahyuni dkk. (2019) selama persalinan, uterus berkontrasi kuat. Kadang-kadang ketika kontraksi seseorang akan merasakan nyeri. Kontraksi otot-otot rahim berlaku ketika prostaglandin dihasilkan. Prostaglandin adalah bahan kimia yang dibuat oleh lapisan rahim. Sebelum melahirkan atau selama persalinan, kadar prostaglandin meningkat.

\section{Nyeri Persalinan setelah dilakukan} Hypnobirthing

Metode hypnobirthing merupakan suatu upaya alami menanamkan niat positif/sugesti kejiwaan/pikiran bawah sadar dalam menjalani masa kehamilan dan persiapan persalinan didasarkan pada keyakinan bahwa setiap perempuan memiliki potensi untuk menjalani proses melahirkan alami, tenang dan nyaman (tanpa rasa sakit) (11).

Dasar hipnosis adalah pemanfaatan kemampuan kita untuk mengakses alam bawah sadar secara langsung. Biasanya kita hanya menyadari pikiran yang ada pada alam sadar. Secara sadar kita berfokus pada sesuatu yang ada di hadapan kita, secara sadar kita berbicara dan mengucapkan kata-kata, atau secara sadar kita berusaha mengingat apa yang telah kita lakukan. Namun saat melakukan halhal tersebut, alam sadar bekerjasama dengan alam bawah sadar (13).

Pengukuran intensitas nyeri persalinan dimulai pada pembukaan IV dan ditetapkan sebagai pre test. Perlakuan hypnobirthing dilakukan pada pembukaan VII dan setiap kali ibu merasakan nyeri sampai pembukaan VIII dan ditetapkan sebagai post test.Untuk kelompok kontrol skala nyeri diukur sebelum dan setelah ibu diberikan KIE.

Setelah diberikan hypnobirthing, responden yang mengalami nyeri ringan mengalami peningkatan $2(16,67 \%)$, nyeri sedang mengalami peningkatan menjadi 8 $(66,67 \%)$ dan responden yang mengalami 
nyeri berat tidak terkontrol berkurang menjadi 0 (0\%). Untuk kelompok control, responden yang mengalami nyeri ringan berkurang menjadi $0(0 \%)$ dan responden yang mengalami nyeri berat terkontrol mengalami peningkatan menjadi 2 $(22,22 \%)$. Selain itu, beradasarkan hasil penelitian Ratih P. (2015) tingkat nyeri ibu bersalin sebelum diberikan hypnobirthing adalah nyeri berat sebanyak $70,0 \%$ dan setelah diberikan hypnobirthing (post test) tingkat nyeri ibu bersalin adalah nyeri sedang sebanyak $90 \%$.

Hasil penelitian Eka Sriwahyuni dkk (2019) bahwa adanya penurunan intesitas nyeri pada ibu primipara yang diberikan hypnobirthing dalam persalinan normal tidak mengalami nyeri (20\%), dan nyeri ringan $(30 \%)$. Sedangkan yang tidak diberikan hypnobirthing mengalami nyeri berat $(100 \%)$. Hasil penelitian lain dilakukan oleh Marfu'ah (2010) dalam Yulrina dan Liza (2015) tentang perbedaan intensitas nyeri pada $30 \mathrm{ibu}$ primipara menunjukkan bahwa ibu yang dilakukan hipnoterapi dalam persalinan normal mengalami nyeri berat ( $40 \%)$, nyeri sedang $(53,3 \%)$, dan nyeri ringan $(6,7 \%)$. Sedangkan yang tidak diberi hipnoterapi mengalami nyeri berat $(66,7 \%)$, nyeri sedang $(30 \%)$ dan nyeri ringan $(3,3 \%)$.

Berdasarkan penjelasan di atas, dapat disimpulkan bahwa penggunaan metode hypnobirthing dapat menurunkan intensitas rasa nyeri dalam persalinan. Hal ini sejalan dengan pendapat dari Andriana (2007) dalam Yunefit dan Mutia (2013) bahwa salah satu manfaat hypnobirthing adalah meminimalkan bahkan menghilangkan rasa takut, ketengan, bahkan sindrom rasa sakit dan kepanikan selama proses persalinan dan periode setelahnya sehingga tidak menjadi trauma.

\section{Pengaruh Hypnobirthing Terhadap Penanggulangan Nyeri pada Masa Persalinan}

Teknik dasar hypnobirthing dibagi atas empat bagian, yaitu pernafasan, relaksasi, visualisasi dan pendalaman yang mana tujuan utamanya untuk mencapai kondisi rileks pada ibu sehingga dapat meningkatkan kenyamanan dan ketenangan ibu menjalani proses persalinan. Kondisi ini akan meminimalkan rasa sakit atau nyeri pada proses persalinan (14).

Hasil analisisbivariat pada kelompok yang dilakukan hypnobirthingpada tingkat kesalahan sebesar $(\alpha) \quad 5 \%$ atau 0,05 (Kepercayaan 95\%) dan diperoleh $\rho$ sebesar 0,000 ; sehingga nilai $\rho<\alpha$ artinya $\mathrm{H}_{0}$ ditolak dan $\mathrm{H}_{\mathrm{a}}$ diterima. Berdasarkan data tersebut diketahui bahwa ada pengaruh yang signifikan (nyata) perlakuan hypnobirthing terhadap penanggulangan rasa nyeri pada masa persalinan di UPT Puskesmas Sukamaju Kab. Luwu Utara Tahun 2020.Dapat disimpulkan bahwa teknik hypnobirthingdapat meminimalkan nyeri persalinan karena dengan hypnobirthing ibu dituntut untuk mencapai kondisi yang sangat rileks dan nyaman pada saat menjalin proses persalinan.

Adanya pengaruh metode hynobirthing pada penanggulangan rasa nyeri pada masa persalinan disebabkan karena metode ini mengajarkan teknik relaksasi alami, sehingga tubuh dapat bekerja dengan seluruh syaraf secara harmonis dan dengan kerjasama penuh, mulai dari relaksasi otot, relaksasi pernafasan, relaksasi pikiran dan penanaman kalimat positif yang dilakukan secara teratur dan konsentrasi akan menyebabkan kondisi rileks pada tubuh sehingga tubuh memberikan respon untuk mengeluarkan hormon endorfin yang membuat ibu menjadi rileks dan menurunkan rasa nyeri terutama ketika otak mencapai gelombang alfa atau saat istirahat. Pada kondisi saat ini, tubuh mengeluarkan hormon serotin dan endorfin sehingga manusia dalam kondisi rileks, santai, antara sadar dan tidak dan nyaris tertidur sehingga tidak merasa tegang dan cemas (14).

Peneliti berusaha untuk meneliti beberapa variable confonding dalam 
penelitian, namun apa yang diharapkan tidak sesuai dengan yang terjadi dilapangan. Skala nyeri seharusnya diukur langsung setelah diberikan intervensi dipembukaan yang sama, bukan dipembukaan yang berbeda sehingga akan mendapatkan hasil sesuai dengan yang diharapakan. Peneliti menyadari masih banyak kekurangan dalam penelitian ini.

\section{UCAPAN TERIMA KASIH}

Peneliti sangat berterima kasih kepada ibu primigravida yang akan bersalin atas kesediaannya menjadi responden. Diucapkan pula terima kasih kepada kepala UPT Puskesmas Sukamaju yang telah memberikan kesempatan untuk melakukan penelitian dan kepada Bidan Asparagus Tyas dan Bidan Lisda Darman yang telah membantu selama penelitian di UPT Puskesmas Sukamaju.

\section{SIMPULAN}

Dari hasil analisis data penelitian diperoleh rata-rata tingkat nyeri ibu primigravida yang bersalin normal dengan perlakuan hypnobirthing(kelompok intervensi) mengalami penurunan tingkat nyeri sedangkan yang tidak dilakukan hypnobirthing (kelompok kontrol) mengalami peningkatan rasa nyeri. Dari hasil analisis data penelitian diperoleh $\rho$ value $=0,000$ dengan taraf kepercayaan $(\alpha)$ $=5 \%$ atau 0,05 . Jadi nilai $\rho$ value $<\alpha$ sehingga dapat disimpulkan bahwa ada pengaruh signifikan (nyata) hypnobirthing terhadap penanggulangan rasa nyeri pada masa persalinan di UPT Puskesmas Sukamaju Tahun 2020.

\section{SARAN}

Disarankan kepada petugas kesehatan khususnya para bidan di UPT Puskesmas Sukamaju agar dalam menangani pasien bersalin normal hendaknya menerapkan metode hypnobirthing untuk membantu ibu dalam mengatasi rasa nyeri karena telah terbukti efektif mengurangi intensitas nyeri persalinan.

Disarankan kepada ibu-ibu primigravida yang akan melakukan persalinan normal, metode hypnobithing merupakan salah satu metode alternatif dalam mengatasi nyeri pada masa persalinan sehingga ibu dapat bersalin dengan aman dan nyaman.

\section{DAFTAR PUSTAKA}

1. Sandi.2018. Apa yang dimaksud dengan Persalinan. https://www.dictio.id/t/apa-yangdimaksud-dengan-persalinan/14779/4. diakses pada tanggal 22 Februari 2020.

2. Titi A., Merah B. 2019. Aplikasi Relaksasi Nafas Dalam terhadap Nyeri dan Lamanya Persalinan Kala I Ibu Bersalin di Rumah Bersalin Kota Bandar Lampung. J. Ilmiah Keperawatan Sai Batik, Vol. 15, No. 1. Hal: $59-65$.

3. Bobak I. M., Lowdermik, D. L., Jensen M. G., Perry, S.E. 2004. Buku Ajar Keperawatan Maternitas. Edisi $\mathrm{Ke}-4$. Jakarta: EGC.

4. Ratih Prananingrum. 2015. Pengaruh Penerapan Hypnobirthing Terhadap Nyeri Persalinan Normal. Profesi, Vol. 13 No. 1. Hal: 44 -46. September 2015.

5. Yulrina A., Liza S., 2015. Pengaruh Teknik Relaksasi Hypnobirthing terhadap Penurunan Rasa Nyeri Kala I Persalinan Normal pada Primipara di BPM Evi. J. Maternity and Neonatal. Vol. 2 No. 2. Hal: 85 - 90.

6. Siti Fatimah. 2017. Pengaruh Penyuluhan tentang Hypnobirthing terhadap Sikap Ibu Primigravidadalam Menghadapi Persalinan (Di Puskesmas Kabuh, Kecamatan Kabuh, Kabupaten Jombang). Skripsi. STIKES Insan Cendikia Medika. Jombang. 
7. Ririn Indriani. 2015. Lanny Kuswandi, Pelopor Hypnobirthing di Indonesia. Suara.c6m.https://www.suara.com/lifes tyle/2015/05/25/125623/lanny-

kuswandi-pelopor-hypnobirthing-diindonesia? page $=3$.

8. Yuseva S., Era Nurisa W., Nur Aini R. H. 2016. Pengaruh Hybnobirthing terhadap tingkat kecemasan ibu bersalin dan lama persalinan di Bidang Praktek Mandiri wilayah Kab. Malang. J. Ilmiah Bidan. Vol. 1, No. 3. Hal: 35 -44 .

9. Kuswandi. 2011. Kehamilan Persalinan dengan Hypnobirthing. PT. Bhuana Ilmu Populer Kelompok Gramedia; Jakarta.

10. Rahmawati, Yusriani, Idris, F. P. 2019. Pengaruh Hypnobirthing terhadap Intensitas Nyeri pada Ibu bersalin Normal di RSUD Labung Baji Makassar. J. Ilmiah Kesehatan Diagnosis. Vol. 14, No. 1. Hal: 67-73. Tahun 2019.

11. Eka Sriwahyuni, Barus, A., Sinambela, M. 2019. Pengaruh Teknik Relaksasi Hypnobirthing terhadap Penurunan Rasa Nyeri Kala I Persalinan Normal pada Primipara di Rumah Sehat Kasih Bunda Kec. Medan Selayang Tahun 2019. J. Penelitian Kebidanan dan Kespro. Vol. 2, No. 1. Hal: 57 - 63.

Oktober 2019.http://ejournal.delihusada.ac.id/i ndex.php/JPK2R.

12. Adam, J., Umboh, J. M. L. 2015. Hubungan antara Usia, Paritas, dan Pendampingan Suami dengan Intensitas Nyeri persalinan Kala I Fase Aktif Deselarasi di Ruang Bersalin RSUD Prof. Dr. H. Aloei Saboe Kota Gorontalo.Artikel Penelitian, Jikmu, Vol. 5, No. 2a. April 2015.

13. Yunefit U., Mutia F. 2013. Pengaruh Hypnobirthing terhadap Nyeri Persalinan di Kec. Sungai Tarap Kab. Tanah Datar Tahun 2013. J. Kes. Mas. STIKES Prima Nusantara Bukittinggi Vol. 4 No. 2. Hal: 54 - 62. Juli 2013.
14. Bandiyah, S., 2009. Kehamilan, Persalinan \& Gangguan Kehamilan. Yogyakarta: Nuha Medika.

15. Hidayat, A. A., 2009. Metode Penelitian Kebidanan Teknik Analisa Data. Jakarta: Salemba Medika. 